Department of Orthopedic Surgery, Medical Faculty, Kyushu University

(Director : Prof. Dr. T. Amako)

\title{
Experience of Internal Fixation with \\ Nail- and Blade-Plate
}

\section{by. Seikei Miyagi}

According to author's experiences of 11 cases with nail- and blade-plate fixation is the method of choice in the treatment of fracture and osteotomy in the region of bone end.

The cases are classified as following table:
Cases
No. of cases

Nail-Plate :

Trochanteric Fracture …......................... 2

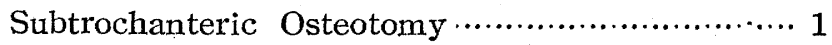

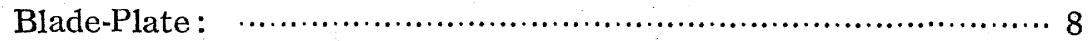

Subtrochanteric Pseudarthrosis …................. 1

Mal-united Fracture of Tibial Condyle ….......... 1 (osteotomy)

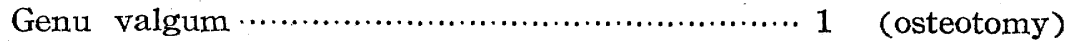

Cubitus varus .......................................... 3 (osteotomy)

Pseudarthrosis of Neck of Humerus ............... 1

Total 11

\section{足固定手石に関する2,3 の考察}

久留米大学整形外科 教授島 㤵吾

\section{1 いとぐち}

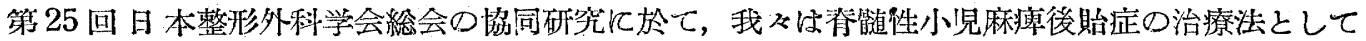
の関節瘾著術及び制動術につんて報告したのでありますが，ての報告に於ては手術效果に重点を特 レた為手術法そのものにつんては多くを述べる レとまがなかつたのであります。

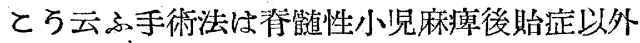
の足障礙にも応用し得るものですり，又手術法 も一見きわめつくされた様にも云はれて居りま すが，さて実際多数の症例に之を行つて見ます と尚色ふと考虑の余地がある様に思はれます。

さて私自身最近の約 3 年閒行行つ手術症例

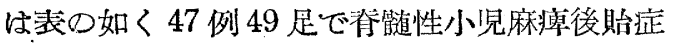

表

最近 3 ケ年間に於ける足固定手術症例

\section{先天性内反足} 例 足 痓直性内反足

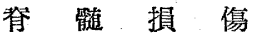

脊 椎 披 裂

ハイネ・メジン氏病 計
3

33

45

11

$36 \quad 36$

$47 \quad 49$ 
が大部分でありますが，其他のものも少数で仕ありますが経験し此較的良い成績を收め得たと思つ て居ります。以下汒等手術経験より本手術につを 2,3 私の考入を中述へて見をんと思ひます。

\section{2 足固定手術としての關節癒著術と制動術}

文献に依りますと初期の足固定手術は距腿関節のみに対して行はれて居つを為，関節癒著術と云 ふのはとの関節の瘾著であり，制動術と云ふのはとの関節の前方文は後方制動術であつた様に思は れます。然しながら其後手術経験を積むに従つて単に距腿関節のみでは充分でないととが明らかに なり，同時に距踵，Chopart 関節にも侵襲を加へる必要があるととが認められる様になり，最近

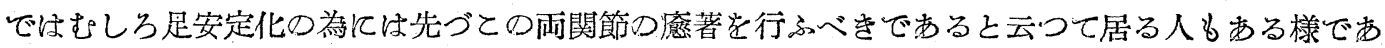
ります。

従つて最近の文献に於ては制動術と云つてすとれは単をる距腿関節の㸲動でをく, 同時に距踵 Chopart 関節瘾著を併用する手術の意味に使はれて居り，文単に関節瘾著術としてあつてもそれは 距腿距踵 Chopart の三関節凂著術をさして居るものが多い様に見ろけられます。即ち現今は足固 定手術としては三関節凂著術か, 距腿関節制動術兼距踵, Chopart 関節瘾著術が主として行はれて 居るものと考へられ，私も特殊なものを除き主としてとの両者を行つて来をのであります。

従つて足安定化の為には常に先づ距踵, Chopart 関節を癒著するととは先づ問題外として距腿 関節を瘾著するか制動に止めるかが問題になる点と考へます。

との問題は中ぬむつかしい問題であり，又単に足のみでをく膝関節やそれ以上の状態も考慮に大 れて決定しなけれ狋らをい為，一概化断定出出来ないのでありますが，私の考へを結論的に中し ますと，少くとも脊髓性小見麻瘏後貽症に於ては，足の底屈背屈に参与し得る筋力が多少とも残つ て居るものは制動術にとぶめたんと思つて居ります。

実際私が経験して来た処では一見在とんど筋力がをい様に思はれるものも，術後の経過を見て居 りますと案外筋機能が残つて居つた事を見出すととが多へのでありまして, 又との点春髓損傷等他 の原因に依る麻瘏と著しく異る点であると教へます。又残存筋力は出来るだけ之を活用し増強する ととも極めて大切な事と考へます。然しながら安定性の点から云へば制動術は瘾著術に比し劣るの

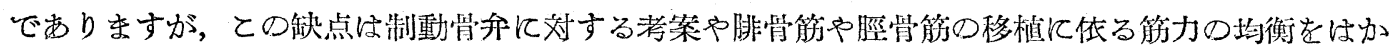
る等の方法で, 或る程度沶ぎをい得るものと考へ之の様手術法を行つて居るのでありますが, 佾 との間題の決定は将来の研究にまたねばをらぬと考へます。

\section{3 距腿關節の Inkongruenz について}

私は前述 49 足の固定術に於て 40 足に制動術を行つをのでありますが，との中 9 足江距腿関節 の Inkongruenz を見て居るのであります。との事については余り記載がない様に思はれますが， 将来種々の障礙を起し折角の手術効果を阻害する大きな原因とをるものと考へますので，その刘策 を考究するととは将来かるる手術を行ふ上に極めて大切右では索いかと考へます。

Inkongruenz の症例は主として成人で且つ変形が高度なものに見られて居るのでありますが， 
若年者や変形が余り強くない下垂足にも認められて居るのであります今その原因並に対策につん て少しく述べて見をんと存じます。

先づ高度の尖足変形があるものは距婯の变形が強く最も Inkongruenz を起す率が多い様に思は れます。Inkongruenz は将来変形性関節症様変化や距骨の厈潰を来す和それがある様に思はれま す。私はて礼が対策としては距骨の Lambrinuidi 式の切除が良んと考へて居ります。

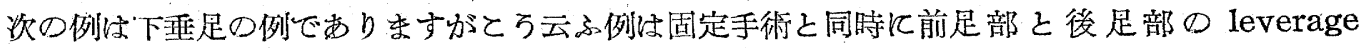
(挺率差)を少くする為，下腿軸に対する足の後方移動の必要があるととは前にも述へだとどあり ますが，その際単に距霄頭の切除のみを行へば少くとも成人に於ては脛骨は之れに附著せる強い鞋

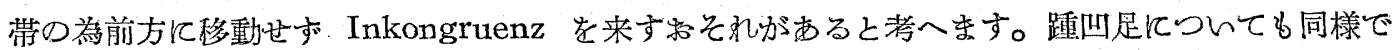

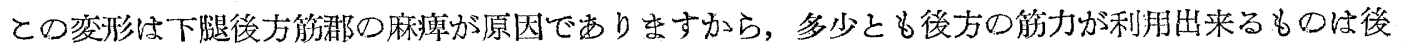
方挺率を増してやれば一層機能力゙良くなるととは当然考へられるととで, ての為には是の後方移動 が必要となります。か」る例で Inkongruenz を防止するには舟状䙹の摘出又は切除を行ふか,

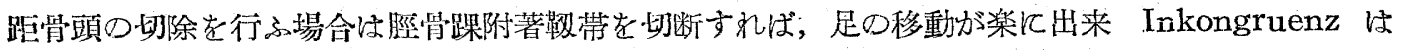
起らないと考へ李す。又 Nové-Josserand 手術に於て踵骨の後方関節面を大きく切つた為に起つ

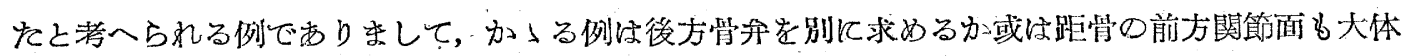
後方々同程度の切除を行ふ必要があるものと考へます。

との他創縁皮膚壊死を7例経験したのでありますが，これはかなり不愉快な合併症で之が対策と して皮膚切開に多少考案を加へて居ります。

又変形矯正に固定術を二次的に行ふととや制動筒弁の問題につんてもんさ」か意見を持つて居る のでありますが，何れ别の機会に発表したんと考へて居ります。

Department of Orthopedic Surgery, Kurume Medical College

Investigation for the Ankle Stabilizing Operations

\section{by Keigo SHIMA}

I investigated the ankle stabilizing operations which had been done for fortyseven cases, forty-nine paralytic ankles in these three years in my clinic.

In conclusion, I prefere bone block operation for paralytic ankle with more or less function of plantar- or dorsi-flexors by poliomyelitis.

In view of stabilization, arthrodesis is more satisfactory than bone block.

Incongruenz of talocrular joint were noted in nine cases of forty bone blocks. It seems that backward displacement of foot by excision of talus or removal of scaphoid obtains more excellent results. 